\title{
Analisis Kualitatif Kemampuan Komunikasi Matematis Siswa Yang Diberi Pembelajaran Matematika Realistik
}

\author{
Marzuki Ahmad $^{1 *}$, Dwi Putria Nasution ${ }^{2}$ \\ ${ }^{1}$ Institut Pendidikan Tapanuli Selatan, Padangsidimpuan, Sumatera Utara 22733, Indonesia \\ ${ }^{2}$ SMA Negeri 2 Padangsidimpuan, Sumatera Utara 22733, Indonesia \\ Pengiriman: 26 Juli 2018; Diterima: 29 September 2018; Publikasi: 30 September 2018 \\ DOI: https://doi.org/10.31629/jg.v3i2.471
}

\begin{abstract}
Abstrak
Artikel ini bertujuan untuk mendeskripsikan kualitas kemampuan komunikasi matematis siswa yang diberi pembelajaran dengan pendekatan Pembelajaran Matematika Realistik (PMR) pada materi segi empat pokok bahasan persegi dan persegi panjang. Jenis penelitian adalah studi kasus deskriptif kualitatif. Subjek penelitian ini adalah siswa kelas VII(6) SMP Negeri 15 Medan yang berjumlah 40 orang, kemudian diangkat subjek yang dianalisis secara kualitatif ditinjau dari aspek indikator kemampuan (tinggi, sedang dan rendah), aspek kesalahan dan aspek jawaban kosong. Instrumen penelitian terdiri dari: Tes kemampuan komunikasi matematis dan lembar panduan wawancara. Teknik analisis data meliputi pengumpulan data, reduksi data, penyajian data dan penarikan kesimpulan. Hasil penelitian menunjukkan bahwa kemampuan komunikasi matematis siswa 22,5\% kategori tinggi, $37,5 \%$ kategori sedang dan $40 \%$ kategori rendah. Selanjutnya melalui analisis kualitatif diperoleh kesimpulan bahwa: 1) Siswa berkemampuan tinggi yaitu mampu dalam berkomunikasi secara matematis dengan baik; 2) Siswa berkemampuan sedang kurang mampu dalam bekomunikasi secara matematis; 3) Siswa berkemampuan rendah tidak mampu berkomunikasi secara matematis; 4) Kesalahan siswa terjadi dalam memahami permasalahan, menggunakan konsep-konsep dan langkah-langkah yang dibutuhkan untuk penyelesaian masalah; 5) Pada jawaban kosong siswa tidak mampu memahami langkah-langkah penyelesaian masalah, siswa kurang mampu dalam menggunakan dan menerapkan operasi hitung, siswa tidak mampu memahami konsep-konsep dalam penyelesaian masalah.
\end{abstract}

Kata kunci: analisis kualitatif; komunikasi matematika; matematika realistik

\begin{abstract}
This article aims to describe the quality of mathematical communication skills of students who are given learning with Realistic Mathematics Education (RME) approach on rectangular material, square and rectangular subject matter. This type of research is a qualitative descriptive case study. The subjects of this study were students of class VII(6) of SMP Negeri 15 Medan totaling 40 people, then the subject was analyzed qualitatively from the aspect of capability indicators (high, medium and low), Error aspects and empty answer aspects. The research instrument consisted of mathematical communication skills test and interview guide sheet. Data analysis techniques included data collection, data reduction, data presentation and conclusion drawing. The results showed that students' mathematical communication skills were $22.5 \%$ in the high category, $37.5 \%$ in the medium category and $40 \%$ in
\end{abstract}




\section{JURNAL GANTANG. September 2018; III(2): 83 - 95 \\ p-ISSN. 2503-0671 \\ e-ISSN. 2548-5547}

the low category. Furthermore, through qualitative analysis, it was concluded that: 1) Students with high abilities are able to communicate mathematically well; 2) Students with average abilities are less capable in communicating mathematically; 3) Low-ability students are not able to communicate mathematically; 4) Student errors occur in understanding problems, using concepts and steps needed to solve problems; 5) In the empty answer students are not able to understand the problem solving steps, students are less able to use and apply the counting operation, students are not able to understand the concepts in solving problems.

Keywords: qualitative analysis; mathematical communication; realistic mathematics

\section{Pendahuluan}

Pengembangan kemampuan

bermatematika khususnya pada kemampuan komunikasi matematis merupakan salah satu focus pembelajaran matematika. Tujuan pembelajaran matematika sebagaimana yang terdapat dalam lampiran Peraturan Pendidikan Mentri Pendidikan Nasional (Permendiknas) Nomor 22 tahun 2006 tentang standar isi terkait dengan kemampuan komunikasi adalah supaya siswa mempunyai kemampuan mengomunikasikan gagasan dengan simbol, tabel, diagram, atau media lain untuk memperjelas keadaan atau masalah (Depdiknas, 2006).

Untuk dapat mencapai kemampuan matematis yang baik, seorang guru hendaknya dapat menciptakan lingkungan belajar yang menyenangkan dan memungkinkan bagi siswa untuk secara aktif belajar dengan mengkonstruksi, menemukan dan mengembangkan pengetahuannya. Dalam hal ini guru perlu membangkitkan aktivitas siswa dalam kegiatan belajar mengajar dengan menanamkan rasa senang terhadap materi pelajaran sesuai materi yang dipelajari dengan memberi rangsangan atau dorongan untuk menyenangi pelajaran matematika (Hamdunah, Fitri, \& Cesaria, 2014). Dengan belajar matematika, diharapkan siswa mampu berkomunikasi secara matematis dalam menyelesaikan masalah. Untuk itu, dalam pembelajaran matematika diharapkan siswa memiliki kemampuan matematis agar dapat mencapai hasil yang memuaskan.

Komunikasi secara umum merupakan suatu peristiwa saling menyampaikan yang terlaksana dalam suatu komunitas dalam situasi budaya (Ansari, 2012). Kemampuan komunikasi matematis dapat diartikan sebagai suatu kemampuan siswa dalam menyampaikan sesuatu yang diketahuinya melalui peristiwa dialog atau saling hubungan yang terjadi dilingkungan kelas, dimana terjadi pengalihan pesan (Nofrianto, Maryuni, \& Amri, 2017). Komunikasi merupakan proses menyampaikan pesan dari seseorang kepada orang lain baik secara langsung (lisan) ataupun tidak langsung (melalui media).

Komunikasi matematis merupakan kemampuan yang penting untuk dimiliki siswa dalam kegiatan pembelajaran. Greenes \& Shulman mengemukakan bahwa: komunikasi matematis adalah (1) pusat kekuatan bagi siswa dalam merumuskan konsep dan stategi pemecahan masalah matematika, (2) modal bagi siswa terhadap pendekatan dan pemecahan masalah dalam eksplorasi dan ivestigasi matematika, (3) wadah bagi siswa dalam berkomunikasi dengan temannya untuk memperoleh penemuan, curah pendapat, menilai dan mempertajam ide matematika (Saragih, 2007). Dalam kegitan pembelajaran berdasarkan arah komunikasi, Gintings (2008) mengklasifikasikan komunikasi menjadi tiga bagian, antara lain; komunikasi linear atau satu arah, komunikasi relasional atau dua arah, dan komunikasi konvergen atau multiarah. Oleh karena itu setiap siswa maupun guru dalam lingkungan kelas dalam penyampaian pesan baik secara lisan maupun tulisan dibutuhkan kemampuan komunikasi yang baik supaya penyampaian informasi yang terjadi dengan baik dan dapat saling memahami. Dalam hal ini siswa 
maupun guru dituntut agar mampu mengkomunikasikan pemikirannya terkait materi yang sedang dipelajari.

Komunikasi matematika merupakan alat bantu dalam transmisi pengetahuan matematika dalam membangun pengetahuan matematika pada kegiatan pembelajaran (Izzati \& Suryadi, 2010). Selanjutnya Baroody (1993) mengungkapkan bahwa dalam komunikasi matematika terdapat beberapa aspek yang harus dipenuhi yaitu kemampuan menyajikan, kemampuan mendengarkan, kemampuan membaca atau memahami, kemampuan mendiskusikan, dan kemampuan menuliskan ide matematika ke dalam bahasa matematika. Selain itu, indikator kemampuan siswa dalam berkomunikasi secara matematis dalam pembelajaran matematika menurut Ansari (2012) adalah (1) menyatakan ide matematika dengan berbicara, menulis, demonstrasi dan menggambarkannya dalam bentuk visual, (2) memahami, menginterpretasi, dan menilai ide matematik yang disajikan dalam tulisan, lisan atau bentuk visual, (3) menggunakan bahasa, notasi dan struktur matematika untuk menyatakan ide, menggambar hubungan dan pembuatan model.

Kemampuan komunikasi matematis dalam penelitian ini adalah kemampuan berkomunikasi matematika secara tulisan. Kemampuan komunikasi matematis diukur melalui: (1) menyatakan permasalahan kehidupan sehari-hari kedalam model atau bahasa matematika, (2) menginterpretasikan gambar ke dalam simbol atau bahasa matematika, (3) menuliskan informasi dari pernyataan ke dalam model atau bahasa matematika.

Berdasarkan pengamatan yang peneliti dilaksanakan di salah satu SMP kota Medan selama 3 (tiga) hari pada bulan Januari tahun 2013 diperoleh informasi bahwa sebagian besar siswa mempunyai kemampuan rendah dalam pelajaran matematika. Hal ini dilihat dari adanya gejala-gejala sebagai berikut: (1) terhadap pertanyaan diajukan oleh guru pada materi yang telah diajarkan yang sebelumnya dan masih hubungannya dengan materi yang akan diajarkan ternyata kebanyakan siswa kurang mengerti materi yang mana yang ada hubungannya, (2) masih banyak siswa yang kurang mampu menyatakan benda nyata, gambar dan diagram ke alam idea matematika dan kurang mampu menyatakan peristiwa sehari-hari dalam bahasa atau simbol matematika (3) sebagian besar siswa tidak mampu menyelesaikan masalah-masalah matematika yang berkaitan dengan dunia real atau masalah yang ada di sekitar siswa. Dari ungkapan ini dapat diduga bahwa kemampuan komunikasi matematis siswa masih rendah. Selanjutnya berdasarkan pemberian tes dignostik yang dilakukan peneliti pada satu kelas disekolah tersebut melaui pemberian tes kemampuan komunikasi matematis siswa juga memberi gambaran bahwa kemampuan komunikasi matematis siswa rendah.

Keberhasilan seorang siswa dalam belajar matematika tergantung pada kemampuan berpikirnya dan kemampuannya dalam berkomunikasi secara matematis. Begitu juga dengan guru, seorang guru harus dapat memilih pendekatan pembelajaran yang sesuai dengan materi pelajaran dan konteks dunia nyata siswa. Paradigma baru pendidikan lebih menekankan pada peserta didik memiliki potensi utama dalam aktivitas sementara guru berperan sebagai fasilitator yang membimbing siswa kearah pembentukan pengetahuan oleh diri mereka sendiri (Hadi, 2017). Dengan demikian perlu memilih pendekatan pembelajaran yang dapat membangkitkan dan mendorong timbulnya aktivitas aktif siswa dalam pembelajaran yang pada akhirnya kemampuan komunikasi matematis siswa dapat meningkat.

Terdapat beberapa pendekatan dalam pembelajaran matematika yaitu pendekatan pemecahan masalah, pendekatan open-ended, pendekatan problem posing, pendekatan pembebelajaran berbasis masalah dan pendekatan pembelajaran matematika realistik. Pendekatan pembelajaran yang memberikan 


\section{JURNAL GANTANG. September 2018; III(2): 83 - 95 \\ p-ISSN. 2503-0671 \\ e-ISSN. 2548-5547}

kesempatan kepada siswa untuk mengkontruksi materi pelajaran dan penekanan seimbang terhadap konsep matematisasi adalah pendekatan Pembelajaran Matematika Realistik (PMR). Pembelajaran dengan pendekatan PMR senantiasa berangkat dari dunia nyata ke dunia simbol/bahasa matematika dan dilanjutkan pada pembentukan konsep matematika yang dilanjutkan dengan menerapkan konsep tersebut dalam pemecahan permasalahan kehidupan sehari-hari.

Hal ini dimungkinkan karena dalam pembelajaran matematika realistik pembelajaran dimulai dari sesuatu yang riil atau sesuatu yang dekat dengan kehidupan nyata siswa. Realistik tidak diharuskan nyata/ada, tetapi juga boleh hanya dapat dibayangkan (Afriansyah, 2016). Sesuatu yang dapat dibayangkan oleh peserta didik yang melakukan kegiatan belajar mengajar terkait konsep yang dipelajari dapat dimanfaatkan dalam proses pembelajaran (Febrian \& Perdana, 2017). Sehingga siswa dapat terlibat dalam proses pembelajaran secara bermakna dan dapat dibermaknakan.

PMR merupakan suatu pendekatan pembelajaran dalam kegiatan belajar mengajar matematika. PMR dikembangkan dengan prinsip dasar, yaitu (1) Guided Reinvention and Progressive Mathematization (Penemuan Terbimbing dan Bermatematika secara Progresif, (2) Didactical Phenomenology (Penomena dalam Pembelajaran dan (3) Selfdeveloped Models (Pengembangan Model Secara Mandiri) (Gravemeijer, 1994). Sesuai dengan prinsif pembelajaran matematika realistik di atas, dalam pembelajaran dengan pendekatan PMR perlu memperhatikan karakteristik PMR sebagaimana yang diungkapkan Treffers yaitu: (1) penggunaan konteks dalam pembelajaran, (2) penggunaan model untuk mengembangkan matematisasi progressif, (3) pemampaatan hasil kontruksi siswa, (4) terjadi Intraktivitas guru dan siswa, (5) keterkaitan materi-materi matematika (Wijaya, 2012).
Peran guru dalam pembelajaran dengan pendekatan PMR adalah sebagai pembimbing dan fasilitator bagi siswa. Siswa tidak dipandang sebagai penerima pasif atau sebagai botol kosong yang harus diisi dengan air akan tetapi, siswa adalah sebagai individu yang memiliki potensi dasar untuk mengembangkan ilmu pengetahuan dalam dirinya yang dapat aktif mengkonstruksi pengetahuannya. Belajar mandiri yang dilakukan siswa terhadap suatu materi tertantu merupakan cara yang efektif dalam menemukan ilmu pengetahuan baru (Hadi, 2017). Selanjutnya di dalam PMR diharapkan siswa tidak sekedar aktif sendiri, tetapi ada aktivitas bersama diantara sesama siswa dan dengan guru (interaktivitas). Dalam pembelajaran siswa seharusnya tidak dianggap sebagai penerima pasif dengan sekedar menggunakan rumus dan prosedur tertentu untuk menyelesaikan suatu permasalahan, tetapi lebih dari itu peserta didik diberi kesempatan dan dibimbing mengembangkan kemampuan bermatematikanya dalam proses penemuan kembali (reinvent) konsep itu sendiri (Mendrofa, 2017). Proses pembelajaran seperti ini, diharapkan dapat meningkatkan kemampuan bermatematika siswa secara optimal.

Beberapa penelitian pendahulu
mengungkapkan bahwa PMR dapat meningkatkan kemampuan komunikasi matematis siswa. Besarnya pencapaian nilai rata-rata kemampuan komunikasi matematis siswa yang diajar melalui PMR lebih baik dari pada melalui pembelajaran biasa dimana melalui PMR diperoleh 63,96 dan melalui pembelajaran konvensional adalah 47,46 (Haji \& Abdullah, 2016). Sementara itu, besarnya peningkatan kemampuan komunikasi matematis siswa yang diajar melalui PMR adalah 0,51. Selanjutnya (Rahmawati, 2013) menyimpulkan bahwa kemampuan komunikasi matematis siswa yang diajar dengan pendekatan pendidikan matematika realistik lebih baik dari pada dengan pendekatan konvensional (ekspositori) dan pendidikan matematika realistik sangat potensial diterapkan dalam 
meningkatkan kemampuan komunikasi matematis.

Penelitian yang dilaksanakan Nofrianto, Maryuni, dan Amri (2017) menyimpulkan bahwa PMR memiliki pengaruh yang signifikan terhadap kemampuan komunikasi matematis siswa. Selanjutnya penelitian Anisa (2014) menyimpulkan bahwa kemampuan komunikasi matematis siswa yang diberi pembelajaran melalui pendekatan PMR lebih baik daripada yang diberi pembelajaran dengan pendekatan pembelajaran langsung.

Dari uraian diatas dapat dipahami bahwa pada berbagai penelitian penerapan PMR dapat memberikan pengaruh positif terhadap kemampuan komunikasi matematika siswa. Dengan adanya kemampuan komunikasi matematis siswa diharapkan dapat menumbuhkan perkembangan kognitif, afektif dan psikomotorik siswa sehingga hasil belajar matematika siswa dapat lebih meningkat. Dalam hal ini penulis tertarik untuk melakukan analisis kualitas kemampuan komunikasi matematis siswa yang diberi pembelajaran dengan pendekatan PMR pada siswa SMP.

\section{Metode Penelitian}

Penelitian ini merupakan penelitian studi kasus deskriptif kualitatif yang bertujuan untuk mendeskripsikan kemampuan komunikasi matematis siswa yang diberi pembelajaran dengan pendekatan Pembelajaran Matematika Realistik (PMR) pada materi segi empat pada pokok bahasan persegi dan persegi panjang. Penelitian dilaksanakan di SMP Negeri 15 Medan, kelas VII(6) pada Tahun Pelajaran 2012/2013, dengan jadwal yang dikoordinasikan dengan kegiatan sekolah yang dilaksanakan pada bulan April sampai bulan Mei-Oktober Tahun 2013. Subjek penelitian adalah siswa kelas VII(6) SMP Negeri 15 Medan yang selanjutnya diangkat subjek yang dikenai wawancara mendalam dengan pertimbangan bahwa siswa dapat memberikan informasi yang jelas terkait dengan kemampuan komunikasi matematis yang ditinjau dari aspek kemampuan komunikasi matematika (tinggi, sedang dan rendah), kesalahan siswa dan jawaban kosong. Analisis data kemampuan komunikasi matematis siswa dilakukan melalui pendekatan kuantitatif dan kualitatif. Dengan katalain analisis kuantitatif dijadikan sebagai fasilitator untuk analisis kualitatif.

Pengumpulan data dalam penelitian dilaksanakan melalui tes kemampuan komunikasi matematis dan wawancara. Tes yang diberikan terkait dengan permasalahan sehari hari siswa dengan salah satu contoh soal "Pak Herman memiliki lukisan pemandangan alam yang dipajang pada dinding rumahnya. Jika lukisan tersebut adalah seperti pada gambar di samping. (a) Informasi apa yang dapat kamu peroleh dari gambar? (b) Tentukan Luas dan Keliling lukisan dan tuliskan kesimpulanya?". Tes dilakukan kepada seluruh siswa (40 orang) yang mengikuti kegiatan pembelajaran dengan pendekatan PMR sebanyak 4 pertemuan. Soal yang digunakan dalam tes disesuaikan dengan kisi-kisi kemampuan komunikasi matematis dan penskoran dilakukan dengan mengacu pada pedoman penskoran yang ditetapkan. Proses pengkategorian siswa dilakukan mengacu pada proses kategori yang ditetapkan pihak sekolah yaitu tinggi sedang dan rendah. Kategori tinggi berada pada interval $80 \leq$ Nilai $\leq 100$, sedang berada pada interval $65 \leq$ Nilai $<80$, rendah berada pada interval $0 \leq$ Nilai $<65$.

Selanjutnya siswa yang terpilih sebagai subjek yang dikenai wawancara diambil lembar jawabannya guna dilakukan pengamatan mendalam untuk mendapatkan deskripsi kemampuan komunikasi matematis awal siswa dari keseluruhan aspek yang diteliti. Selanjutnya dilakukan, wawancara mendalam terhadap kemampuan siswa dan wawancara terhadap guru mata pelajaran yang menerapkan pelaksanaan PMR. Penelitian studi kasus merupakan studi yang mengeksplorasi suatu masalah dengan batasan terperinci, memiliki pengambilan data 
JURNAL GANTANG. September 2018; III(2): 83 - 95

p-ISSN. 2503-0671

e-ISSN. 2548-5547

yang mendalam dan menyertakan berbagai sumber informasi (Rangkuti, 2016). Wawancara dilaksanakan bukan teknik yang bersifat tambahan/sekedar melengkapi data, tetapi merupakan teknik utama bersama dengan observasi (Putra, 2011). Dengan demikian wawancara secara mendalam dilaksanakan terhadap siswa terpilih dan guru hingga data yang diharapkan diperoleh dengan lengkap dan jenuh.

Wawancara merupakan percakapan yang dilaksanakan maksud tertentu (Moleong, 2011). Wawancara dalam hal ini dilakukan untuk mendapatkan realistas kualitas kemampuan komunikasi matematis siswa yang diberi pembelajaran dengan PMR. Proses pengumpulan data yang dilaksanakan tidak terlepas dari analisis data yang dilakukan. Adapun analisis data yang dilakukan meliputi pengumpulan data, penyajian data, reduksi data dan penarikan kesimpulan.

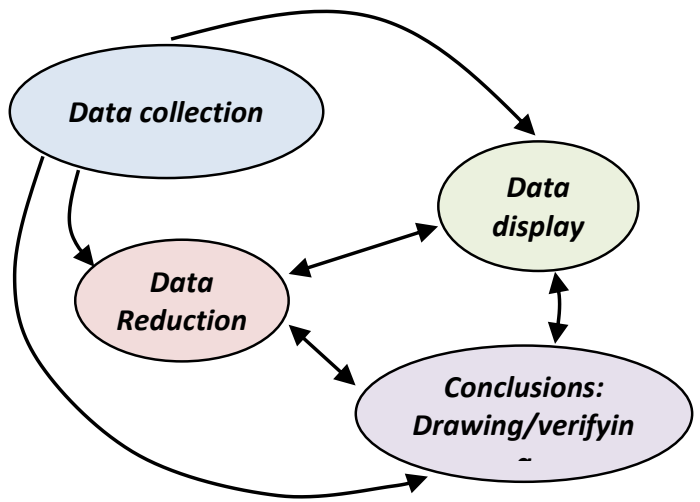

Gambar 1. Komponen dalam Analisis Data

(Sugiyono, 2012)

\section{a. Reduksi Data (Data Reductions)}

Reduksi data merupakan langkah awal dalam menganalisa data. Tujuannya adalah untuk memudahkan pemahaman terhadap data yang telah terkumpul. Mereduksi data berarti merangkum, memilih hal-hal yang pokok, memfokuskan pada hal-hal yang penting, dicari tema dan polanya (Sugiyono, 2012). Reduksi data dalam penelitian ini adalah kegitan menyeleksi, memfokuskan, mengabstraksi dan memformulasikan semua data yang diperoleh dari lapangan. Kegiatan yang dilakukan adalah sebagai berikut

1. Memeriksa hasil tes dan mengadakan analisis untuk mendapatkan kategorisasi dan pengelompokan pola jawaban siswa. Pengelompokan pola jawaban siswa ditinjau dari indikator kemampuan, kesalahankesalahan siswa, dan jawaban kosong. Berdasarkan tinjauan tehadap hasil tes tersebut di bentuk lima kelompok pola jawaban siswa, antara lain: tiga kategori pola jawaban mengacu pada indikator kemampuan; satu kategori pola jawaban mengacu pada kesalahan-kesalahan siswa; dan satu kategori pola jawaban lagi dari jawaban kosong.

2. Membuat transkrip rekaman hasil wawancara setiap subjek penelitian dan wawancara terhadap guru. Rekaman hasil wawancara subjek dipadukan dengan catatan-catatan selama wawancara, sebab sebagian wawancara adalah dalam bentuk tertulis. Untuk itu kaset rekaman diputar dan dicatat berulang ulang sampai jelas tentang apa yang diungkapkan subjek dalam wawancara. Pada kesempatan ini data-data yang tidak perlu dibuang (direduksi). Hasil wawancara ini dianalisis untuk menentukan deskripsi kualitas kemampuan komunikasi matematis siswa dengan PMR.

\section{b. Penyajian Data (Data display)}

Setelah data direduksi maka langkah selanjutnya adalah penyajian data atau mendisplay data. Penyajian data adalah penulisan kembali kumpulan data/informasi yang terorganisasi dan terkategori, sehingga memungkinkan untuk melakukan penarikan kesimpulan dari data tersebut. Penyajian data dalam penelitian ini meliputi; Penyajian data analisis hasil tes kemampuan komunikasi matematis yang dipadukan dengan hasil wawancara dengan siswa (subjek penelitian) dan wawancara dengan guru dari masing-masing aspek yang dianalisis.

\section{c. Kesimpulan (Conclusions)}

Penarikan kesimpulan dilakukan berdasarkan analisis terhadap data yang 
dikumpulkan, baik melalui tes maupun wawancara dan catatan lapangan. Penarikan kesimpulan ini meliputi deskripsi kualitas kemampuan komunikasi matematis siswa yang diberi pembelajaran dengan pendekatan PMR yang ditinjau dari aspek indicator: aspek kesalahan siswa; aspek jawaban unik; dan aspek jawaban kosong.

\section{Hasil dan Pembahasan}

Secara kuantitatif, tingkat kemampuan komunikasi matematis siswa dari hasil tes dapat dilihat pada diagram batang berikut ini:

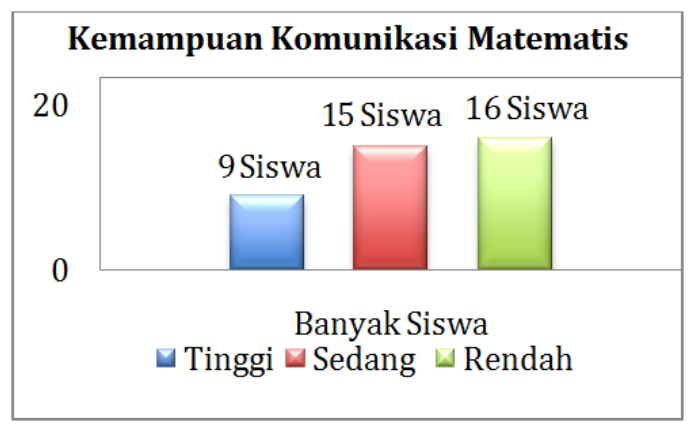

Gambar 2. Tingkat Kemampuan Komunikasi Matematis Siswa

Dari gambar 1. dapat dililhat bahwa tingkat kemampuan komunikasi matematis siswa pada kategori tinggi yaitu terdapat 9 siswa atau sebesar 22,5\%, pada kategori sedang terdapat 15 siswa atau sebesar $37,5 \%$ dan pada kategori rendah terdapat 16 siswa atau sebesar $40 \%$.

Sesuai dengan rancangan metode penelitian diangkat siswa yang dikenai wawancara, maka dalam penelitian ini diangkat subjek yang dikenai wawancara mendalam ditinjau dari aspek indikator kemampuan (tinggi, sedang dan rendah), aspek kesalahan, dan aspek jawaban unik. Pengangkatan subjek tersebut dilakukan antaralain dari aspek indikator kemampuan tinggi, sedang dan rendah masingmasing diangkat satu siswa, dari aspek kesalahan diangkat dua siswa dan dari aspek jawaban kosong diangkat satu siswa. Sehingga jumlah keseluruhan siswa yang dianalisis sebanyak 6 (enam) siswa.

Berdasarkan hasil analisis lembar jawaban dengan pertimbangan terhadap kesediaan siswa untuk dianalisis serta dapat memberi informasi yang bersifat akurat tentang kemampuan komunikasi matematis siswa dari subjek utama diangkat siswa yang dianalisis secara kualitatif sebagaimana terdapat pada tabel berikut.

Tabel 1.

Siswa yang terpilih sebagai subjek wawancara

\begin{tabular}{|c|l|l|l|}
\hline No. & \multicolumn{1}{|c|}{$\begin{array}{c}\text { Aspek } \\
\text { Pengangkatan } \\
\text { Subjek }\end{array}$} & Kode siswa & $\begin{array}{c}\text { Jenis } \\
\text { Kelamin }\end{array}$ \\
\hline 1. & Kemampuan tinggi & SKM-1 & Laki-Laki \\
\hline 2. & Kemampuan sedang & SKM-14 & Perempuan \\
\hline 3. & Kemampuan rendah & SKM-25 & Perempuan \\
\hline 4. & Kesalahan & SKM-34 & Laki-Laki \\
\cline { 2 - 4 } 5. & Jawaban kosong & SKM-2 & Laki-Laki \\
\hline
\end{tabular}

Ket: SKM= Subjek Komunikasi Matematis

Degan terpilihnya subjek wawancara dilaksanakan wawancara mendalam terhadap subjek pada seluruh butir soal yang diujikan dalam tes dan dilanjutkan dengan wawancara terhadap guru yang menerapkan PMR. Selanjutnya berdasarkan tes kemampuan komunikasi matematis yang telah dilaksanakan SKM-1 terpilih sebagai subjek yang wawancara mendalam dari aspek kemampuan tinggi. Berikut dibawah ini akan diuraikan analisis tentang hasil tes kemampuan komunikasi matematis siswa SKM-1 untuk soal nomor 1 yang diujikan pada tes kemampuan komunikasi matematis.

Soal nomor 1 bertujuan untuk menentukan kemampuan komunikasi matematis siswa dalam menginterpretasikan gambar ke dalam model matematika menentukan tentang bagaimana sifat-sifat persegi panjang dalam menentukan pasangan sisi yang sama panjang, pasangan sisi yang sejajar, sisi yang tidak sama panjang, sudut siku-siku, diagonal dan membuat kesimpulan. Adapun soal yang dimaksud adalah "Perhatikan gambar sketsa permukaan papan tulis dalam bentuk persegi panjang PQRS, Tuliskanlah: (a) Pasangan sisi yang sama panjang; (b) Pasangan sisi yang sejajar; (c) Sisi yang tidak sama panjang; (d) Semua sudut sikusiku dari persegi; (e)

panjang PQRS; $(f)$ 


\section{JURNAL GANTANG. September 2018; III(2): 83 - 95

Diagonal pada persegi panjang; (g) Apa yang dapat kamu simpulkan dari persegi panjang PQRS?". Adapun jawaban SKM-1 adalah sebagai berikut.

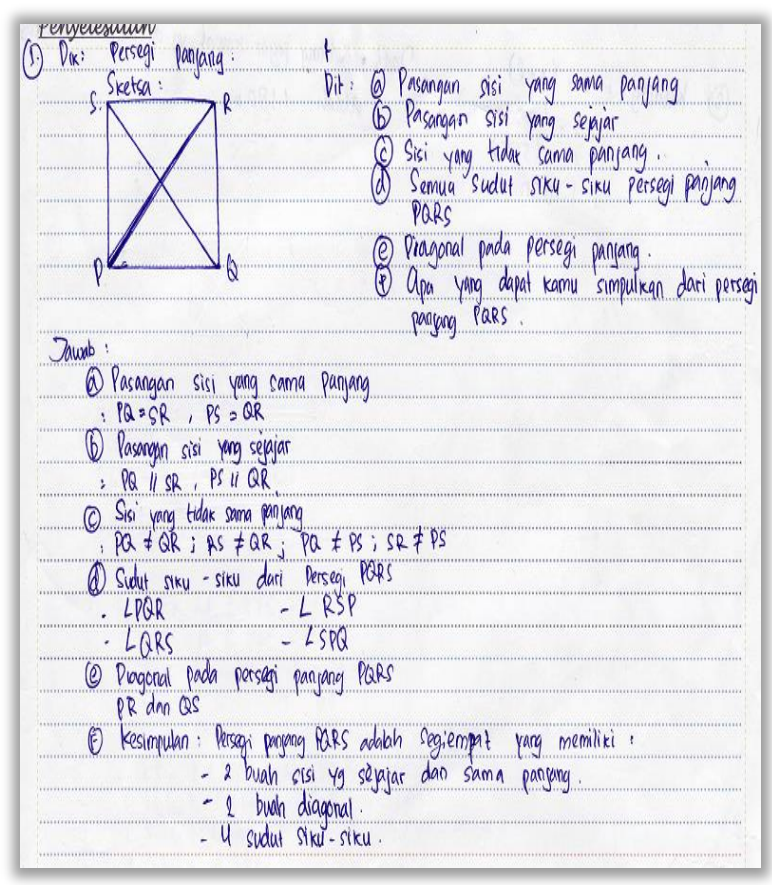

Gambar 3. Jawaban kemampuan komunikasi matematis siswa nomor 1

Berdasarkan jawaban diatas dapat diperhatikan bahwa siswa dapat menyelesaikan soal komunikasi matematis dalam menginterpretasikan gambar ke dalam model matematika tentang menentukan bagaimana sifat-sifat persegi panjang dalam menentukan pasangan sisi yang sama panjang, pasangan sisi yang sejajar, sisi yang tidak sama panjang, sudut siku-siku, diagonal dan membuat kesimpulandan kemampuan komunikasi matematis siswa memenuhi standar indikator, dimana siswa dapat menyelesaikan permasalahan nomor 1 dengan jelas dan komunikasinya terpenuhi. Berdasarkan jawaban siswa peneliti mendeskripsikan ditinjau dari aspek indikator bahwa dalam menginterpretasikan gambar ke dalam model matematika yaitu siswa memahami sifat-sifat gambar persegi panjang yang diberikan, siswa mampu menggunakan bahasa matematika dan simbol secara tepat baik dalam penulisan sisi sisi yang sama panjang, sisi yang sejajar, sisi yang tidak sama panjang, dan menuliskan sudut serta dalam menuliskan kesimpulan.

Berikut dibawah ini disajikan transkrip wawancara terhadap SKM-1 sebagai triangulasi dari deskripsi pengamatan tentang lembar jawaban siswa.

Transkrip Wawancara SKM-1, No.1

$\mathrm{P} \quad$ : Saya tertarik dengan jawaban yang anda berikan waktu tes. Kita akan membicarakan tentang jawaban anda tersebut ya! Sekarang coba anda bacakan soal nomor 1 tes kemampuan komunikasi matematis

SKM-1 : (Membaca soal)

Perhatikan gambar persegi panjang PQRS di bawah ini. Tuliskanlah! (a) Pasangan sisi yang sama panjang; (b) Pasangan Sisi yang sejajar; (c) Sisi yang tidak sama panjang; (d) Semua sudut siku-siku dari persegi panjang PQRS; (e) Diagonal pada persegi panjang; (f) Apa yang dapat kamu simpulkan dari persegi panjang PQRS.

$\mathrm{P} \quad$ : Apakah bisa memahami soal tersebut?

SKM-1 : Saya paham pak.

$\mathrm{P} \quad$ : Apa kira-kira yang anda pahami dari soal tersebut?

SKM-1 : Persegi panjang PQRS.

$\mathrm{P} \quad$ : Coba sebutkan yang diketahui!

SKM-1 : Yang diketahi dalam soal adalah persegi panjang PQRS.

$\mathrm{P} \quad$ : Apa kira-kira yang ditanyaan dari soal tersebut?

SKM-1 : Yang ditanyakan adalah (a) Pasangan sisi yang sama panjang; (b) Pasangan Sisi yang sejajar; (c) Sisi yang tidak sama panjang; (d) Semua sudut sikusiku; (e) Diagonal sisi; (f) kesimpulkan dari persegi panjang PQRS.

$\mathrm{P}$ : Berdasarkan persegi panjang PQRS, manakah dari sisi tersebut yang merupakan sisi yang sama panjang?

SKM-1 : Sisi PQ sama panjang dengan sisi SR dan sisi PS sama dengan sisi QR.

$\mathrm{P} \quad$ : Apakah sisi PQ tidak sama panjang dengan sisi QR?

SKM-1 : Tidak.

$\mathrm{P} \quad$ : Kemudian tentang pasangan sisi yang sejajar, Manakah dari gambar yang merupakan sisi yang sejajar? 
SKM-1 : Sisi PQ sejajar dengan sisi SR dan sisi PS sejajar dengan sisi QR.

$\mathrm{P}$ : Sisi mana yang tidak sama panjang?

SKM-1 : PQ tidak sama panjang dengan $Q R$, RS tidak sama panjang dengan $Q R$, PQ tidak sama panjang dengan PS, SR tidak sama panjang dengan PS.

P Kemudian, apakah pada persegi panjang $\mathrm{PQRS}$ ini terdapat diagonal?

SKM-1 Ada.

P Coba anda sebutkan diagonal-diagonal tersebut!

SKM-1 Diagonal PR dengan diagonal QS.

$\mathrm{P}$ : Kemudian coba sebutkan diagonaldiagonal yang ada pada persegi panjang tersebut.

SKM-1 : Diagonal sisi PR dan diagonal sisi QS.

$\mathrm{P}$ : Apa yang dapat kamu simpulkan tentang persegi panjang PQRS tersebut?

SKM-1 : Kesimpulannya adalah: persegi panjang PQRS adalah bagun segi empat yang memiliki dua buah sisi yang sejajar dan sama panjang dua buah diagonal dan empat buah sudut siku-siku.

P Anda mengatakan empat sudut sikusiku, dari mana anda mengatakan hal tersebut?

SKM-1 Dari sketsa Pak.

P : Coba anda sebutkan empat sudut tersebut!

SKM-1 : Semua sudut siku-siku dari persegi panjang $\mathrm{PQRS}$ adalah $\angle \mathrm{PQR}, \angle$ QRS, $\angle \mathrm{RSP}, \angle \mathrm{SPQ}$.

$\mathrm{P}$ : Oke... Baik, terimakasih

SKM-1 : Sama-sama.

Berdasarkan data kutipan wawancara diatas siswa dapat memberi jawaban wawancara dimana siswa dapat memberikan informasi yang dari gambar kedalam model matematika dan dapat memberikan kesimpulan sesuai dengan pemahamannya seuai dengan impormasi yang diperoleh dari gambar. Dengan membandingkan hasil pengamatan dari lembar jawaban siswa dan hasil wawancara terhadap subjek maka berdasarkan wawancara yang diperoleh dideskripsikan

bahwa;

Dalam

menginterpretasikan gambar ke dalam model matematika yaitu siswa memahami sifat-sifat gambar yang diberikan, siswa mampu menggunakan bahasa matematika dan simbol secara tepat, siswa dapat menginterpretasikan gambar ke dalam model matematika dengan lengkap dan benar.

Berdasarkan temuan penelitian sesuai dengan teknik analisis data yang dilakukan maka pada pembahasan penelitian yang dilakukan terhadap keseluruan aspek dapat ditarik kesimpulan (Conclusions) kemampuan komunikasi matematis siswa yang diberi pembelajaran dengan pendekatan PMR sebagai berikut.

a. Kemampuan komunikasi matematis siswa kategori tinggi.

Berdasarkan tinjauan dari aspek indikator kemampuan dalam Menyatakan masalah kehidupan sehari-hari kedalam model atau bahasa matematika diperoleh temuan penelitian bahwa Siswa dapat memahami permasalahan dengan baik, siswa memahami model atau bahasa matematik dengan baik, siswa dapat menuliskan masalah kehidupan sehari-hari kedalam model atau bahasa matematika dengan lengkap dan benar disimpulkan bahwa siswa mampu menyatakan masalah kehidupan seharihari kedalam model atau bahasa matematika dengan baik dan benar.

\begin{tabular}{rrrr}
\multicolumn{2}{c}{ Berdasarkan tinjauan dari aspek } \\
indikator $\quad$ kemampuan & & dalam
\end{tabular}

Menginterpretasikan gambar ke dalam model matematika diperoleh temuan penelitian bahwa siswa memahami sifat-sifat gambar yang diberikan, siswa mampu menggunakan bahasa matematika dan simbol secara tepat, siswa dapat menginterpretasikan gambar ke dalam model matematika dengan lengkap dan benar disimpulkan bahwa siswa mampu menginterpretasikan gambar ke dalam model matematika dengan lengkap dan benar.

Berdasarkan tinjauan dari aspek indikator kemampuan dalam menuliskan informasi dari pernyataan kedalam bahasa 


\section{JURNAL GANTANG. September 2018; III(2): 83 - 95 \\ p-ISSN. 2503-0671 \\ e-ISSN. 2548-5547}

matematika diperoleh temuan penelitian bahwa siswa dapat memahami pernyataan dengan baik, siswa mampu menuliskan pernyataan yang kedalam bahasa matematika, siswa mampu menggunakan istilah-istilah untuk menginformasikannya kedalam bahasa matematika, siswa dapat mengubah imformasi yang terdapat di dalam pernyataan kedalam bahasa matematika disimpulkan bahwa siswa mampu menuliskan informasi dari pernyataan kedalam bahasa matematika lengkap dan benar.

b. Kemampuan komunikasi matematis siswa ketegori sedang.

Berdasarkan tinjauan dari aspek Indikator kemampuan dalam Menyatakan masalah kehidupan sehari-hari kedalam model atau bahasa matematika diperoleh temuan penelitian bahwa sebagian besar siswa mampu memahami permasalahan dengan baik, sebagian besar siswa mampu memahami model atau bahasa matematik dengan baik, sebagian besar siswa mampu menuliskan masalah kehidupan sehari-hari kedalam model atau bahasa matematika dengan lengkap dan benar disimpulkan bahwa siswa hampir mampu menyatakan masalah kehidupan sehari-hari kedalam model atau bahasa matematika dengan baik dan benar.

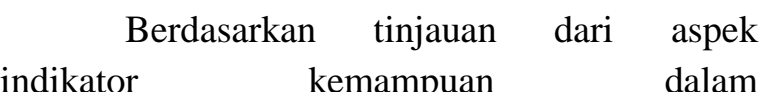

Menginterpretasikan gambar ke dalam model matematika diperoleh temuan penelitian bahwa sebagian besar siswa mampu memahami sifatsifat gambar yang diberikan, sebagian besar siswa mampu menggunakan bahasa matematika dan simbol secara tepat, sebagian besar siswa dapat menginterpretasikan gambar ke dalam model matematika dengan lengkap dan benar disimpulkan bahwa siswa hampir mampu dalam menginterpretasikan gambar ke dalam model matematika dengan lengkap dan benar.

Berdasarkan tinjauan dari aspek indikator kemampuan dalam menuliskan informasi dari pernyataan kedalam bahasa matematika diperoleh temuan penelitian bahwa sebagian besar siswa mampu memahami pernyataan dengan baik, sebagian besar siswa mampu mengubah imformasi yang terdapat di dalam pernyataan kedalam bahasa matematika, sebagian besar siswa mampu menuliskan pernyataan yang kedalam bahasa matematika, sebagian besar siswa mampu menggunakan istilah-istilah untuk menginformasikannya kedalam bahasa matematika disimpulkan bahwa siswa hampir mampu menuliskan informasi dari pernyataan kedalam bahasa matematika lengkap dan benar.

c. Kemampuan komunikasi matematis siswa kategori rendah.

Berdasarkan tinjauan dari aspek indikator kemampuan dalam menyatakan masalah kehidupan sehari-hari kedalam model atau bahasa matematika diperoleh temuan penelitian bahwa Siswa hanya sebahagian kecil memahami permasalahan dengan baik, siswa hanya sebahagian kecil memahami model atau bahasa matematik dengan baik, siswa hanya sebahagian kecil dapat menuliskan masalah kehidupan sehari-hari kedalam model atau bahasa matematika dengan lengkap dan benar. disimpulkan bahwa siswa kurang mampu menyatakan masalah kehidupan sehari-hari kedalam model atau bahasa matematika dengan baik dan benar.

$\begin{array}{rrrr}\text { Berdasarkan tinjauan dari aspek } \\ \text { indikator } \quad \text { kemampuan } & & \text { dalam }\end{array}$

Menginterpretasikan gambar ke dalam model matematika diperoleh temuan penelitian bahwa Siswa hanya sebahagian kecil memahami sifatsifat gambar yang diberikan, siswa hanya sebahagian kecil mampu menggunakan bahasa matematika dan simbol secara tepat, siswa hanya sebahagian kecil dapat menginterpretasikan gambar ke dalam model matematika dengan lengkap dan benar disimpulkan bahwa siswa kurang mampu dalam menginterpretasikan gambar ke dalam model matematika dengan lengkap dan benar.

Berdasarkan tinjauan dari aspek indikator kemampuan dalam menuliskan informasi dari pernyataan kedalam bahasa matematika diperoleh temuan penelitian bahwa 
siswa hanya sebahagian kecil dapat memahami pernyataan dengan baik, siswa hanya sebahagian kecil dapat mengubah imformasi yang terdapat di dalam pernyataan kedalam bahasa matematika, siswa hanya sebahagian kecil mampu menuliskan pernyataan yang kedalam bahasa matematika, siswa hanya sebahagian kecil mampu menggunakan istilah-istilah untuk menginformasikannya kedalam bahasa matematika disimpulkan bahwa siswa kurang mampu menuliskan informasi dari pernyataan kedalam bahasa matematika lengkap dan benar.

d. Kesalahan siswa dalam menyelesaikan soal komunikasi matematis.

Berdasarkan tinjauan dari aspek kesalahan dalam memahami permasalahan diperoleh temuan penelitian bahwa Siswa tidak bisa menuliskan permasalahan dengan lengkap, siswa tidak terbiasa dengan pemecahan masalah, siswa kurang mampu mengaitkan permasalahan realistik kepada model atau symbol matematik disimpulkan bahwa siswa kurang mampu dalam memahami permaslahan matematika realistik.

Berdasarkan tinjauan dari aspek kesalahan dalam memahami konsep-konsep yang diperlukan dalam menyelesaikan permasalahan diperoleh temuan penelitian bahwa siswa kurang mampu memahami materi prasyarat, siswa kurang mampu meggunakan konsep-konsep yang telah dipelajari untuk menyelesaikan permasalahan disimpulkan bahwa siswa kurang mampu dalam memahami konsep-konsep yang diperlukan untuk menyelesaikan permasalahan matematika realistik.

Berdasarkan tinjauan dari aspek kesalahan dalam menggunakan operasi hitung diperoleh temuan penelitian bahwa siswa keliru dalam perhitungan, sebagian dari perhitungan susah bagi siswa disimpulkan bahwa siswa kurang mampu dalam menggunakan operasi hitung.

Berdasarkan tinjauan dari aspek kesalahan dalam memahami langkah-langkah penyelesaian masalah diperoleh temuan penelitian bahwa siswa tidak terbiasa menyelesaikan masalah yang membutuhkan langkah-langkah penyelesaian disimpulkan bahwa siswa kurang mampu dalam memahami langkah-langkah yang dibutuhkan untuk penyelesaian masalah.

e. Siswa yang memiliki jawaban kosong.

Berdasarkan tinjauan dari aspek jawaban kosong dalam memahami langkah-langkah penyelesaian masalah diperoleh temuan penelitian bahwa siswa tidak mampu memahami permasalahan yang terdapat pada soal disimpulkan bahwa siswa tidak memahami langkah-langkah penyelesaian masalah.

Berdasarkan tinjauan dari aspek jawaban kosong dalam menggunakan operasi hitung diperoleh temuan penelitian bahwa siswa kurang lancar dalam operasi penjumlahan dan pengurangan, siswa kurang lancar dalam operasi perkalian dan pembagian disimpulkan bahwa siswa kurang mampu dalam menggunakan dan menerapkan operasi hitung.

Berdasarkan tinjauan dari aspek jawaban kosong dalam memahami konsep-konsep yang diperlukan dalam menyelesaikan permasalahan diperoleh temuan penelitian bahwa siswa tidak memahami konsep persegi panjang, siswa tidak memahami konsep persegi disimpulkan bahwa siswa kurang mampu memahami konsep-konsep yang diperlukan dalam menyelesaikan permasalahan.

\section{Kesimpulan}

Hasil penelitian menunjukkan bahwa kemampuan komunikasi matematis siswa setelah pembelajaran adalah 22,5\% kategori tinggi, $37,5 \%$ kategori sedang dan 40\% kategori rendah melalui analisis wawancara diperoleh bahwa: 1) siswa berkemampuan tinggi mampu dengan baik dalam berkomunikasi secara matematis, 2) pada siswa berkemampuan sedang yaitu kurang mampu dalam bekomunikasi secara matematis, 3) siswa berkemampuan rendah tidak mampu berkomunikasi secara matematis, 4) kesalahan siswa terjadi dalam memahami permasalahan, menggunakan konsep-konsep dan langkahlangkah yang dibutuhkan untuk penyelesaian masalah, 5) pada jawaban kosong siswa tidak 


\section{JURNAL GANTANG. September 2018; III(2): 83 - 95 \\ p-ISSN. 2503-0671 \\ e-ISSN. 2548-5547}

mampu memahami langkah-langkah penyelesaian masalah, siswa kurang mampu dalam menggunakan dan menerapkan operasi hitung, siswa tidak mampu memahami konsepkonsep dalam penyelesaian masalah.

Bagi tenaga pendidik disarankan agar dapat menerapkan pendekatan Pembelajaran Matematika Realistik sebagai alternatif pendekatan pembelajran dalam kegiatan belajar mengajar matematika dengan lebih memperhatikan siswa kelompok yang memiliki kemampuan rendah agar siswa tersebut tidak mengalami ketertinggalan dalam mencapai target dan tujuan pembelajaran.

\section{Ucapan Terimakasih}

Penulis mengucapkan terimakasih kepada Bapak Kepala SMP Negeri 15 Medan beserta seluruh dewan guru yang telah memberikan kesempatan dan izin kepada penulis untuk melakukan penelitian dan khususnya kepada ibu guru mata pelajaran matematika kelas VII(6) Tahun ajaran 2012/2013 telah aktif dalam penerapan pelaksanaan kegiatan pembelajaran matematika realistik.

\section{Referensi}

Afriansyah, E. A. (2016). Makna realistic dalam RME dan PMRI. LEMMA, II(2), 96-104. https://doi.org/10.22202/j1.2016.v2i2.578

Anisa, W. N. (2014). Peningkatan kemampuan pemecahan masalah dan komunikasi matematik melalui pembelajaran pendidikan matematika realistik untuk siswa SMP Negeri di Kabupaten Garut. Jurnal Pendidikan dan Keguruan (Vol. 1). Retrieved from http://pasca.ut.ac.id/journal/index.php/JPK/ article/download/12/12

Ansari, B. I. (2012). Komunikasi matematika dan politik suatu perbandingan: konsep dan aplikasi. Banda Aceh: Yayasan PeNA.

Baroody, A. J. (1993). Problem solving, reasoning, and communicating. New York: Macmillan Publishing.

Depdiknas. (2006). Peraturan Menteri Pendidikan Nasional Republik Indonesia
Nomor 22 Tahun 2006 Tentang Standar Isi untuk Satuan Pendidikan Dasar dan Menengah, 0-595.

Febrian, \& Perdana, S. A. (2017). Memfasilitasi penalaran geometri transformasi siswa melalui eksplorasi motif melayu dengan bantuan grid. Jurnal Gantang, II(2), 157164. https://doi.org/10.31629/jg.v2i2.250

Gintings, A. (2008). Esensi praktis belajar dan pembelajaran. Bandung: Humaniora.

Gravemeijer, K. (1994). Develoving realistic mahematics education. Urecht: CD-B Presh.

Hadi, S. (2017). Pendidikan matematika realistik: teori, pengembangan, dan implementasinya. Jakarta: PT Raja Grafindo Persada.

Haji, S., \& Abdullah, M. I. (2016). Peningkatan kemampuan komunikasi matematika melalui pembelajaran matematika realistik. Infinity Journal, 5(1), 42-49. Retrieved from http://ejournal.stkipsiliwangi.ac.id/index.php/infini ty/article/view/190

Hamdunah, Fitri, D. Y., \& Cesaria, A. (2014). Pelatihan jarimatika perkalian bagi guruguru di SDN 02 Lubuk Buaya. LEMMA, $I(1), \quad 20-25 . \quad$ Retrieved from http://ejournal.stkip-pgri-

sumbar.ac.id/index.php/jurnal-

lemma/article/view/586/365.

Izzati, N., \& Suryadi, D. (2010). Komunikasi matematik dan pendidikan matematika realistik. Prosiding seminar nasional matematika dan pendidikan matematika, 721-729. Retrieved from https://bundaiza.files.wordpress.com/2012/ 12/komunikasi_matematik_dan_pmrprosiding.pdf

Mendrofa, N. K. (2017). Pengembangan alur pembelajaran perbandingan berbasis realistic mathematics education untuk siswa kelas VII SMP. LEMMA, III(2), 117. Retrieved from http://ejournal.stkippgri-sumbar.ac.id/index.php/jurnallemma/article/view/1907/pdf 
Moleong, L. J. (2011). Metodologi penelitian kualitatif. Bandung: Pt Remaja Rosda Karya.

Nofrianto, A., Maryuni, N., \& Amri, M. A. (2017). Komunikasi matematis siswa: pengaruh pendekatan matematika realistik. Jurnal Gantang, II(2), 113-123. https://doi.org/10.31629/jg.v2i2.199

Putra, N. (2011). Penelitian kualitatif: proses dan aplikasi. Jakarta: PT Indeks.

Rahmawati, F. (2013). Pengaruh pendekatan pendidikan realistik matematika dalam meningkatkan kemampuan komunikasi matematis siswa sekolah dasar. Prosiding SEMIRATA 2013, 1(1), 225-238. Retrieved from

http://jurnal.fmipa.unila.ac.id/index.php/se mirata/article/view/882

Rangkuti, A. N. (2016). Metode penelitian pendidikan pendekatan kuantitatif, kualitatif, PTK dan penelitian pengembangan. Bandung: Cipta Pustaka Mulia.

Saragih, S. (2007). Mengembangkan kemampuan berpikir logis dan komunikasi matematik siswa sekolah menengah pertama melalui pendekatan matematika realistik. Disertasi UPI Bandung: Tidak diterbitkan.

Sugiyono. (2012). Memahami penelitian kualitatif. Bandung: Alfabeta.

Wijaya, A. (2012). Pendidikan matematika realistik: suatu alternatif pendekatan pembelajaran matematika. Yogyakarta: Graha Ilmu. 